\title{
Penile cancer: a case series in two tertiary care teaching hospitals with review of literature
}

\author{
Arghya Basu ${ }^{1}$, Arnab Mondal ${ }^{2}$, Harish Kela ${ }^{2}$ \\ 'Department of Oncology, B.R. Singh Hospital \& Research Centre, Kolkata, West Bengal, India \\ ${ }^{2}$ Department of General Surgery, IPGMER \& SSKM Hospital, Kolkata, West Bengal, India
}

Keywords: Penile cancer; squamous cell carcinoma; penectomy; inguinal node dissection

\begin{abstract}
Introduction

Carcinoma of penis is a very rare disease most commonly affecting elderly men. This rare disease can have terrible and horrifying consequences on the social and emotional life of patients as well as their families. The objective of our case series is to describe the sociodemographic and clinical features, the standard investigations and treatment protocols and follow up of patients who presented to our hospitals.
\end{abstract}

\section{Methodology}

This is a prospective study of fourteen patients admitted in two tertiary care teaching institutions of Kolkata between January 2013 to December 2015 with a histopathological diagnosis of penile cancer.

\section{Results and discussion}

Age of patients varied between 45 to 82 years. Duration of disease varied between 3-13 months. Nine patients had palpable inguinal lymphadenopathy and 2 patients had liver metastases. Eight patients underwent partial amputation of penis and 4 patients underwent total amputation.

\section{Conclusion}

Penile cancer is a rare disease with devastating consequences. Patients often present late and the primary surgical treatment is often disfiguring. Aggressive surgical treatment of the primary disease and groin remains the cornerstone in the management of high-risk cases.

\section{Introduction}

Carcinoma of penis is a rare disease commonly affecting elderly men, with Brazil being the country with highest

\footnotetext{
Correspondence: Arghya Basu

E-mail: dr.arghyarox@gmail.com

Received: 18-09-2017 Accepted: 13-11-2017

(iD) http://orcid.org/0000-0003-4074-6547

DOI: http://doi.org/10.4038/sljs.v35i4.8433
}

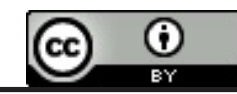

incidence [1]. It usually refers to squamous cell carcinomas (SCC) of penis, however, it encompasses non-squamous malignant lesions also. It is less frequent in countries with higher socioeconomic status like Europe and United States, accounting for $0.4-0.6 \%$ of all malignancies, but comparatively commoner in countries with low and middle socioeconomic status like Africa and South America, representing almost $10 \%$ of all malignancies [2]. The peak incidence is seen during sixth decade of life. Of these cases, $19 \%$ occur below 40 years and $7 \%$ below 30 years. The annual age-adjusted rate of penile cancer is $2.3-8.3$ per 100000 men [3].

Poor hygiene, phimosis, dermatitis, regional trauma, smoking and infection with Human Papilloma Virus (HPV) are known etiological factors [4]. Neonatal circumcision is presumed to be a protective factor as the incidence rate of carcinoma of penis is very low in countries where neonatal circumcision is routinely practiced [5]. Ninety five percent of penile cancers arise from squamous epithelium of glans $(80 \%)$ or foreskin $(15 \%)$ in the form of ulceroproliferative growth , localized or invading the whole penis.

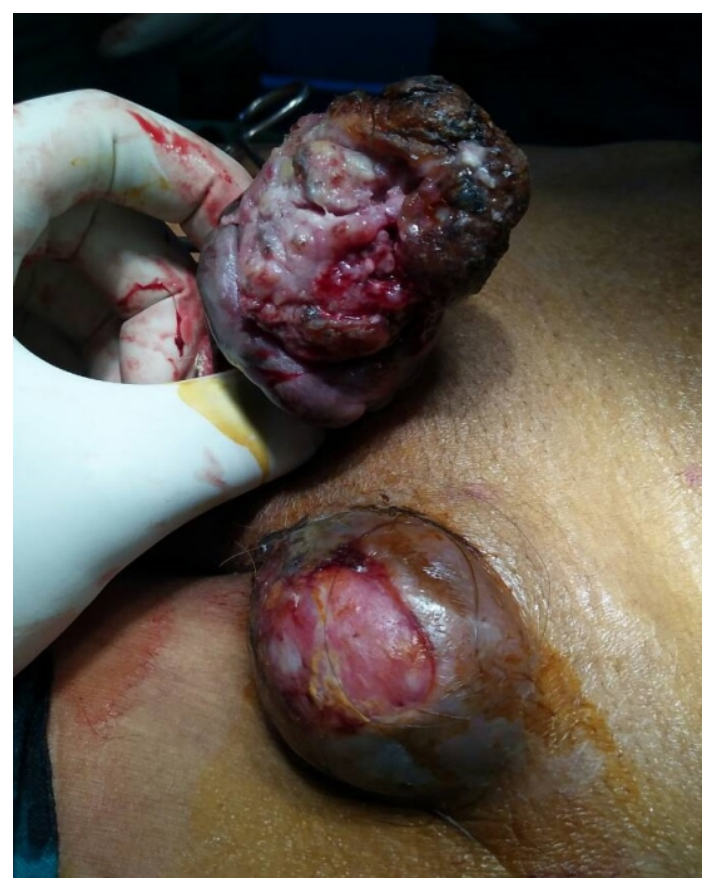

Figure 1. Ca Penis with left inguinal lymphadenopathy 
Penile cancer can have terrible and horrifying consequences on the social and emotional life of patients as well as their families. Presentation is usually late as it is more prevalent in people from low socioeconomic status who come to the hospital mostly when they are debilitated by the disease. Hence a thorough knowledge about the sociodemographic factors, adoption of potential prevention strategies and aggressive treatment regimes are not only necessary but also essential to mitigate this disease. The objective of our case series is to describe the sociodemographic and clinical features, the standard investigations and treatment protocols and follow up of patients who presented to our hospitals between $2013-2015$.

\section{Materials and methods}

We performed this prospective study with fourteen patients admitted to Department of Surgical Oncology in two tertiary care teaching hospitals in Kolkata between January 2013 to December 2015 with a histopathological diagnosis of penile cancer. History, diagnosis, histopathology reports, extension, stage, margin of resection, treatment and events encountered during follow up period were noted. The international TNM classification system was used for staging. Sociodemographic characteristics, clinical features and histopathological characteristics were subjected to special attention. Patients were followed up every three months during the first follow up year and every six months thereafter, provided there was no complication or recurrence.

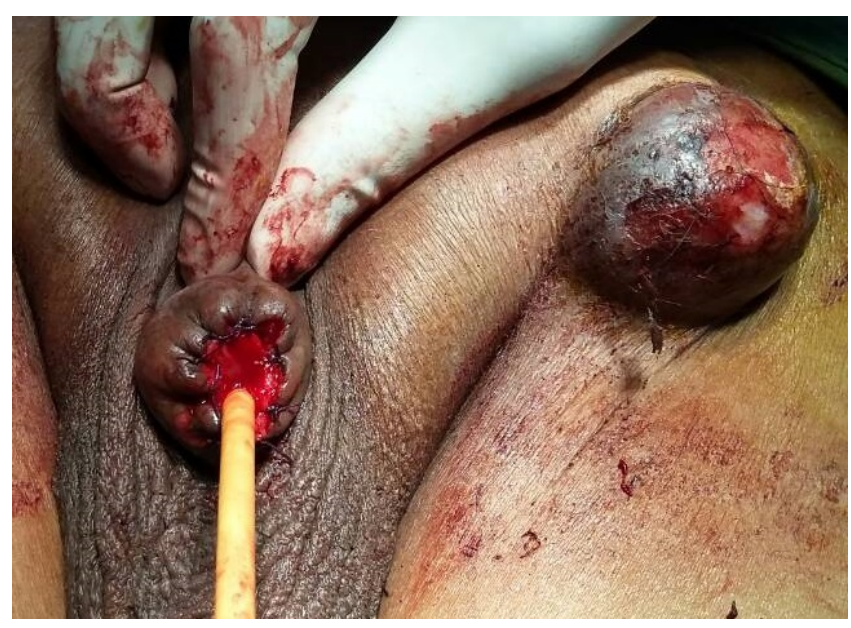

Figure 2. Post-op picture after partial penectomy

\section{Results}

The demographic, clinical, staging, treatment and follow up data are tabulated in the following two tables (Table 1A \& 1B). Age of patients varied between 45 to 82 years. 5 patients had diabetes, 5 patients had hypertension, 3 patients had ischemic heart disease. Duration of disease varied between 3-13 months. All the patients presented with ulcers involving the penis, 9 were $\mathrm{p} \mathrm{T} 1-\mathrm{p}$ T2 and 5 were infiltrating the urethra ( $p-T 3)$. Nine patients had palpable inguinal lymphadenopathy and 2 patients had liver metastases. Two patients were found to have welldifferentiated squamous cell carcinoma, 5 patients were found to have moderately differentiated squamous cell carcinoma, 6 patients were found to have poorly differentiated squamous cell carcinoma and 1 patient had diffuse large Bcell lymphoma. Eight patients underwent partial penectomy and 4 patients underwent total penectomy. Two patients with metastatic disease were treated with palliative amputation and palliative chemotherapy. One patient with lymphoma was treated with primary chemotherapy. The patients were followed up for 8- 48 months. Two patients with liver metastasis progressed during the course of the disease and eventually died.

\section{Review of literature}

Penile cancer is a disease of elderly males which may have devastating effect on the lives of patients as well as their families. The age distribution of penile cancer patients in our study was compatible with the literature [6]. Infection by Human Papilloma Virus, smoking, phimosis and poor local hygiene have been described as common etiological factors, while early circumcision has been described to be protective. All the patients in our study were uncircumcised and 6 of them had phimosis. Retention of smegma leads to chronic irritation and inflammation of the glans and prepuce in uncircumcised males which has carcinogenic effects [7]. Circumcision gives protection against penile cancer by preventing development of phimosis, collection of smegma, formation of lichen sclerosus and decreasing the risk of infection by HPV type 16 and 18. More than $40 \%$ patients are HPV positive and have positive correlation with number of sexual partners. In our study 5 patients were HPV positive evident by presence of malpigiennes cells infected with HPV i.e. koilocytes.

Glans and prepuce are usually involved early by the disease which gradually engulfs the entire glans, shaft,corpora even up to scrotum [8]. In our study patients had a delay of 4-13 months before seeking medical attention. It was mostly due to ignorance, shyness, shame, guilt, fear, lack of pain, lack of education and personal neglect. Penile cancer usually appears as an indurated, painless nodule, warty growth, ulcer or exophytic mass with foul odour and/or bloody or purulent discharge. In our study, besides ulcer, patients also presented with itching, inguinal lump and features of lower urinary tract symptoms (LUTS). More than $95 \%$ of the cases are squamous cell carcinoma, however, melanocytic lesions, mesenchymal tumours, lymphomas and metastases have also been reported [9]. In our study poorly differentiated squamous cell carcinoma was most frequent. We performed deep biopsy in all patients to assess the depth of invasion. In case of palpable inguinal lymphadenopathy refractory to conservative treatment, we performed ultrasound guided FNAC which enhanced the micrometa-stasis detection rate. 
Table 1A: Demographic, clinical, staging, treatment and follow up data of patients 1-7

\begin{tabular}{|c|c|c|c|c|c|c|c|}
\hline Patient & P1 & P2 & P3 & P4 & P5 & P6 & P7 \\
\hline Age & 63 & 55 & 73 & 59 & 52 & 64 & 82 \\
\hline $\begin{array}{l}\text { Cigarette } \\
\text { Smoking }\end{array}$ & Yes & Yes & Yes & No & No & Yes & Yes \\
\hline $\begin{array}{l}\text { Multiple Sex } \\
\text { Partner }\end{array}$ & Yes & Yes & No & Yes & No & No & No \\
\hline Foreskin status & Uncircumcised & Uncircumcised & Uncircumcised & Phimosis & Phimosis & Uncircumcised & Phimosis \\
\hline Location & Glans & $\begin{array}{l}\text { Glans, distal } \\
\text { shaft }\end{array}$ & Body & $\begin{array}{l}\text { Balanoprepucial } \\
\text { groove }\end{array}$ & $\begin{array}{l}\text { Glans, } \\
\text { prepuce, } \\
\text { distal shaft }\end{array}$ & $\begin{array}{l}\text { Glans, } \\
\text { balanoprepucial } \\
\text { groove }\end{array}$ & $\begin{array}{l}\text { Effaced } \\
\text { Penis }\end{array}$ \\
\hline Comorbidity & Nil & $\mathrm{DM}, \mathrm{HTN}$ & $\mathrm{DM}$ & $\mathrm{DM}, \mathrm{IHD}$ & Nil & $\mathrm{HTN}$ & IHD \\
\hline $\begin{array}{l}\text { Duration of } \\
\text { disease } \\
\text { (months) }\end{array}$ & 5 & 7 & 3 & 8 & 12 & 10 & 6 \\
\hline $\begin{array}{l}\text { Clinical feature } \\
\text { (Other than } \\
\text { ulcer) }\end{array}$ & $\begin{array}{l}\text { Discharge, } \\
\text { redness }\end{array}$ & $\begin{array}{l}\text { Bloody } \\
\text { discharge, } \\
\text { itching }\end{array}$ & $\begin{array}{l}\text { Inguinal lump, } \\
\text { penile } \\
\text { erythema }\end{array}$ & $\begin{array}{l}\text { Pus discharge, } \\
\text { erythema, } \\
\text { inguinal lump }\end{array}$ & LUTS & LUTS & $\begin{array}{l}\text { Bloody } \\
\text { discharge, } \\
\text { Itching, } \\
\text { LUTS }\end{array}$ \\
\hline $\mathrm{T}$ (tumour) & T1 & T1 & T3 & T3 & T2 & $\mathrm{T} 1$ & $\mathrm{T3}$ \\
\hline $\mathrm{N}$ ( node) & NO & NO & N3 & N3 & N1 & NO & N2 \\
\hline M(metastases) & - & - & + & - & - & - & - \\
\hline Histology & MDSCC & WDSCC & $\mathrm{PDSCC}$ & PDSCC & MDSCC & $\begin{array}{l}\text { Diffuse Large B- } \\
\text { Cell Lymphoma }\end{array}$ & PDSCC \\
\hline $\begin{array}{l}\text { Presence of } \\
\text { Pre-malignant } \\
\text { lesion }\end{array}$ & - & + & + & - & - & - & - \\
\hline $\begin{array}{l}\text { Presence of } \\
\text { HPV }\end{array}$ & - & + & + & - & - & - & + \\
\hline $\begin{array}{l}\text { Preoperative } \\
\text { assessment }\end{array}$ & CT & CT & MRI & MRI & СТ & CT & MRI \\
\hline $\begin{array}{l}\text { Treatment of } \\
\text { primary } \\
\text { tumour }\end{array}$ & $\begin{array}{l}\text { Partial } \\
\text { penectomy }\end{array}$ & $\begin{array}{l}\text { Partial } \\
\text { penectomy }\end{array}$ & $\begin{array}{l}\text { Total } \\
\text { penectomy } \\
\text { (palliative) } \\
\end{array}$ & Total penectomy & $\begin{array}{l}\text { Partial } \\
\text { penectomy }\end{array}$ & $\begin{array}{l}\text { Primary } \\
\text { chemotherapy }\end{array}$ & $\begin{array}{l}\text { Partial } \\
\text { penectomy }\end{array}$ \\
\hline $\begin{array}{l}\text { Treatment of } \\
\text { lymph node }\end{array}$ & Surveillance & $\begin{array}{l}\text { Antibiotics, } \\
\text { surveillance }\end{array}$ & $\begin{array}{l}\text { Palliative } \\
\text { chemotherapy }\end{array}$ & B/L LND, EBRT. & U/L LND & $\begin{array}{l}\text { Primary } \\
\text { chemotherapy }\end{array}$ & $\begin{array}{l}\text { B/LLND, } \\
\text { EBRT. }\end{array}$ \\
\hline $\begin{array}{l}\text { Progression } \\
\text { during follow- } \\
\text { up }\end{array}$ & - & - & + & - & - & - & - \\
\hline Death & - & - & + & - & - & - & - \\
\hline $\begin{array}{l}\text { Follow up } \\
\text { period } \\
\text { (months) }\end{array}$ & 48 & 36 & 11 & 27 & 32 & 16 & 28 \\
\hline
\end{tabular}

DM : diabetes mellitus, HTN : hypertension, IHD : ischaemic heart disease, LUTS : lower urinary tract symptoms, EBRT : external beam radiation therapy, LND : lymph node dissection, WDSCC : well differentiated squamous cell carcinoma, MDSCC: moderately differentiated squamous cell carcinoma, PDSCC : poorly differentiated squamous cell carcinoma, CT: computed tomography, MRI : magnetic resonance imaging. 
Table 1B : Demographic, clinical, staging, treatment and follow up data of patients 8-14

\begin{tabular}{|c|c|c|c|c|c|c|c|}
\hline Patient & P8 & P9 & P10 & P11 & P12 & P13 & P14 \\
\hline Age & 53 & 45 & 68 & 39 & 55 & 49 & 69 \\
\hline $\begin{array}{l}\text { Cigarette } \\
\text { Smoking }\end{array}$ & No & No & Yes & Yes & Yes & Yes & Yes \\
\hline $\begin{array}{l}\text { Multiple Sex } \\
\text { Partner }\end{array}$ & No & Yes & Yes & No & No & No & No \\
\hline Foreskin status & Phimosis & Uncircumcised & Phimosis & Uncircumcised & Phimosis & Uncircumcised & Uncircumcised \\
\hline Location & Body & Distal shaft & $\begin{array}{l}\text { Glans, } \\
\text { prepuce }\end{array}$ & $\begin{array}{l}\text { Balanoprepucial } \\
\text { groove }\end{array}$ & $\begin{array}{l}\text { Distal shaft, } \\
\text { glans }\end{array}$ & Effaced penis & Body \\
\hline Comorbidity & $\mathrm{DM}, \mathrm{HTN}$ & $\mathrm{DM}, \mathrm{IHD}$ & HTN & Nil & Nil & Nil & HTN \\
\hline $\begin{array}{l}\text { Duration of } \\
\text { disease } \\
\text { (months) }\end{array}$ & 7 & 12 & 4 & 8 & 11 & 13 & 5 \\
\hline $\begin{array}{l}\text { Presenting } \\
\text { Symptom } \\
\text { (Other than } \\
\text { ulcer) }\end{array}$ & LUTS & $\begin{array}{l}\text { Inguinal lump, } \\
\text { penile } \\
\text { erythema }\end{array}$ & $\begin{array}{l}\text { Bloody } \\
\text { discharg } \\
\text { e, } \\
\text { itching, } \\
\text { inguinal } \\
\text { lump }\end{array}$ & $\begin{array}{l}\text { Pus discharge, } \\
\text { erythema, } \\
\text { inguinal lump }\end{array}$ & $\begin{array}{l}\text { Discharge, } \\
\text { redness. }\end{array}$ & $\begin{array}{l}\text { Bloody } \\
\text { discharge, } \\
\text { Itching }\end{array}$ & LUTS \\
\hline $\mathrm{T}$ (tumour) & $\mathrm{T} 2$ & T3 & $\mathrm{T} 2$ & $\mathrm{~T} 2$ & $\mathrm{~T} 1$ & T3 & $\mathrm{T} 2$ \\
\hline $\mathrm{N}$ ( node) & N1 & N3 & N2 & N2 & No & N1 & NO \\
\hline M(metastases) & - & + & - & - & - & - & - \\
\hline Histology & MDSCC & PDSCC & MDSCC & PDSCC & MDSCC & WDSCC & PDSCC \\
\hline $\begin{array}{l}\text { Presence of } \\
\text { Pre-malignant } \\
\text { lesion }\end{array}$ & - & - & + & - & - & - & - \\
\hline $\begin{array}{l}\text { Presence of } \\
\text { HPV }\end{array}$ & + & - & - & + & - & - & + \\
\hline $\begin{array}{l}\text { Preoperative } \\
\text { assessment }\end{array}$ & CT & MRI & MRI & MRI & CT & CT & CT \\
\hline $\begin{array}{l}\text { Treatment of } \\
\text { primary } \\
\text { tumour }\end{array}$ & $\begin{array}{l}\text { Partial } \\
\text { penecto } \\
\text { my }\end{array}$ & $\begin{array}{l}\text { Total } \\
\text { penectomy } \\
\text { (palliative) } \\
\end{array}$ & $\begin{array}{l}\text { Total } \\
\text { penecto } \\
\text { my }\end{array}$ & Total penectomy & $\begin{array}{l}\text { Partial } \\
\text { penectomy }\end{array}$ & $\begin{array}{l}\text { Partial } \\
\text { penectomy }\end{array}$ & $\begin{array}{l}\text { Partial } \\
\text { penectomy }\end{array}$ \\
\hline $\begin{array}{l}\text { Treatment of } \\
\text { lymph node }\end{array}$ & $\mathrm{U} / \mathrm{L}$ LND & $\begin{array}{l}\text { Palliative } \\
\text { chemotherapy }\end{array}$ & $\mathrm{B} / \mathrm{L}$ LND & B/L LND, EBRT. & Surveillance & $\begin{array}{l}\text { Antibiotics, } \\
\text { surveillance }\end{array}$ & $\begin{array}{l}\text { Antibiotics, } \\
\text { surveillance }\end{array}$ \\
\hline $\begin{array}{l}\text { Progression } \\
\text { during follow- } \\
\text { up }\end{array}$ & - & + & - & - & - & - & - \\
\hline Death & - & + & - & - & - & - & - \\
\hline $\begin{array}{l}\text { Follow up } \\
\text { period } \\
\text { (months) }\end{array}$ & 42 & 16 & 23 & 8 & 22 & 31 & 46 \\
\hline
\end{tabular}

DM : diabetes mellitus, HTN : hypertension, IHD : ischaemic heart disease, LUTS : lower urinary tract symptoms, EBRT : external beam radiation therapy, LND : lymph node dissection, WDSCC : well differentiated squamous cell carcinoma, MDSCC : moderately differentiated squamous cell carcinoma, PDSCC : poorly differentiated squamous cell carcinoma, CT : computed tomography, MRI : magnetic resonance imaging. 
In case of palpable lymphadenopathy with negative FNAC we prescribed 4-6 weeks of antibiotics, followed by repeat FNAC if persistent, followed by excisi-onal lymph node biopsy if still negative but highly suspicious and lastly prophylactic lymphadenectomy. CT or MRI were prescribed when clinical examination was difficult like in obese patients or when gross significant lymphadenopathy was present with high suspicion of pelvic spread. MRI has been proven to have higher sensitivity and specificity in detecting and quantifying nodal burden [10]. Artificial erection with contrast enhanced MRI is often useful where exact T-staging is required for organ-preserving surgery.

Penile cancer most frequently spreads to inguinofemoral lymph nodes. Prepucial lymphatics join the network of cutaneous lymphatics of shaft and drain to superficial inguinal nodes whereas glanular lymphatics in the majority drain directly to the deep inguinal nodes, which in turn drains into deep inguinal nodes. Lung, bone and liver are the commonest sites for metastasis. Metastatic cases may present without locoregional lymphad-enopathy, however, metastatic patients in our study presented with heavy locoregional lymph node burden [11]. Metastatic work-up must be done in a patient with proven positive locoregional lymphadenopathy.

Surgical amputation remains the standard treatment for definitive management of penile cancer along with adjuvant modalities. Glans - sparing procedures like limited excision with or without circumcision, Mohs micrographic surgery, laser therapy and radiotherapy may be offered in early stage (Tis, Ta, T1) tumours with favourable histology with the aim of preservation of penile length and sensation.

In our study we preferred conventional partial or total amputation in patients presenting with high stage, significant lymphadenopathy and non-favourable histologies. As per literature, in case of partial amputation we spared a stump of at least 2-3 cm [12]. We performed palliative amputation even in metastatic setting to offer a better quality of life to the patients and their families. Primary chemotherapy was given in a solitary patient of diffuse large B-cell lymphoma without any surgical intervention.

Surgical intervention of groin is indicated in patients with significant inguinal lymphadenopathy, either non-responding to medical management or proven as metastatic by FNAC. Decision regarding extent of lymphadenectomy is critical because it carries significant morbidity as high as 50\% [13]. Complications like surgical site infection (1.2-1.4\%), flap necrosis (0.6-4.7\%), lymphoedema (5-13.9\%), lymphocele (2.1-4\%), phlebitis and rarely pulmonary embolism[14] have been reported. However, Catalona's technique of modified superficialinguinal lymphadenectomy may reduce complication rates with similar long term results [15], but radical procedure must be followed if invasion of lymph node is confirmed histologically.

None of our patients were offered primary chemotherapy except those with metastases who required palliative chemotherapy (bleomycin, cisplatin, methotrexate) and a patient with lymphoma who received primary chemotherapy. Adjuvant chemotherapy may be offered after surgical resection in high risk patients. Cisplatin has shown promising result in presence of large, immobile, palpable inguinal nodes, even as neoadjuvant. Palliative chemotherapy has been used in unresectable primary tumours, fixed, bulky or relapsed inguinal nodes and in presence of distant metastasis but without much promising result [16]. Adjuvant radiotherapy was prescribed depending on positive lymph nodes, perineural or lymphovascular invasion, margin status and extra-capsular extension. Usually clinically palpable lymphadenopathy is found in $28-64 \%$ of patients, $47-85 \%$ of which are due to metastasis and rest due to infection and inflammation. $12-20 \%$ of patients without palpable lymph nodes harbour occult metastasis [17]. Early inguinal lymphadenectomy is prognostically better than surveillance and delayed lymphadenectomy [18].

In advanced cases (T1,G3 or T2-4) aggressive management of groin is highly solicited. There is no role of curative radiotherapy in metastatic groin nodes. Low and intermediate risk cases (Tis, Ta, T1 G1-2) can be managed by cautious surveillance but high risk cases (T2-4) should be offered bilateral superficial inguinal lymphadenectomy with frozen section or complete lymphadenectomy (modified or radical). Dynamic sentinel node biopsy has high sensitivity in detecting clinically occult groin nodes with low morbidity compared to complete lymphadenectomy [19].

Regular follow-up of the patients were done for at least 2 years as $74.3 \%$ of all recurrences, $66.4 \%$ of local recurrences, $86.1 \%$ of regional recurrences and $100 \%$ of distant recurrences are known to occur within first two post-operative years [20]. Our patients were followed up every 3 months during the first post-op year and every 6 months during the 2 nd post-op year in absence of progression or oncological recurrence.

\section{Conclusion}

Patients with penile cancer often present late and the primary surgical treatment is often disfiguring. HPV is an important risk factor. Early circumcision, though reducing incidence, does not offer total protection. Lymph node involvement appears to be the main prognostic factor, therefore, accurate staging and appropriate decision-making regarding groin is of utmost importance. Aggressive surgical treatment of the primary disease and groin remains the cornerstone in the management of high-risk cases. However, a larger series is required to establish standard integrated multimodality treatment protocol for this deleterious disease. 
All authors disclose no conflict of interest. The study was conducted in accordance with the ethical standards of the relevant institutional or national ethics committee and the Helsinki Declaration of 1975, as revised in 2000 .

\section{References}

1. Velazquez EF, Cubilla AL. Penile squamous cell carcinoma : anatomic, pathologic and viral studies in Paraguay (1993 - 2007) Anal Quant Cytol Histol. 2007 Aug; 29(4): 185-98. PMid: 17879626

2. Jemal A, Siegel R, Ward E, Murray T, Xu J, Thun MJ. Cancer Statistics, 2007. CA Cancer J Clin. 2007 Jan-Feb;57(1):43-66. https://doi.org/10.3322/canjclin.57.1.43

3. Favorito LA, Nardi AC, Ronalsa M, Zequi SC, Sampaio FJ, Glina S. Epidemiologic study on penile cancer in Brazil. Int Braz JUrol. 2008 Sep Sep-Oct;34(5):587-93.

4. Calmon MF, Tasso Mota M, Vassallo J, Rahal P. Penile carcinoma : risk factors and molecular alterations. Scientific World Journal. 2011 Feb 3; 11: 269-82. https://doi.org/10.1100/tsw.2011.24

5. Madsen BS, Van den Brule AJ, Jensen HL, Wohlfart J, Frisch M. Risk factors for squamous cell carcinoma of the penis population based case-control study in Denmark. Cancer Epidemiol Biomarkers Prev. 2008 Oct; 17(10): 2683-91. https://doi.org/10.1158/1055-9965.EPI-08-0456

6. Pettaway CA, Pagliaro L, Theodore C, Haas G. Treatment of visceral, unresectable, or bulky/unresectable regional metastases of penile cancer. Urology. 2010; 76(2): S58- S65. https://doi.org/10.1016/j.urology.2010.03.082

7. D'Hauwers K, Depuydt C, Bogers J, Noel J, Delvenne P, Marbaix E, et al. Human papillomavirus, lichen sclerosus and penile cancer :a study in Belgium.Vaccine. 2012; 30(46):6573-7. https://doi.org/10.1016/j.vaccine.2012.08.034

8. Daling JR, Madeleine MM, Johnson LG, Schwartz SM, Shera KA, Wurscher MA, et al. Penile cancer : importance of circumcision, human papillomavirus and smoking in in-situ and invasive disease. Int J Cancer. 2005 Sep 10; 116(4): 606-16. https://doi.org/10.1002/ijc.21009

9. Amine Slaoui, Youness Jabbour, Anouar El Ghazoui, Tarik Karmouni, Khalid Elkhader, Abdelatif Koutani, Ahmed Ibn Attaya . Penile cancer : about ten cases at the University Hospital of Rabat, review of the literature. Pan African Medical Journal. $2015 ; 22: 53$ doi : 10.11604 / pamj.2015.22.53.6563.

10. Kayes O, Ahmed HU, Arya M, Minhas S. Molecular and genetic pathways in penile cancer . Lancet Oncol. 2007 May; 8(5): 420-9. https://doi.org/10.1016/S1470-2045(07)70137-7

11. Barnholtz- Sloan JS, Maldonado JL, Pow-Sang J, Guiliano AR. Incidence trends in primary malignant penile cancer. Urologic Oncology : Seminars and original investigations ; 2007: Elsevier ; 2007. P. 361-7.

12. Rigaud J, Avances C, Camparo P, Durand X, Flechon A, Murez T, Sebe P, Coloby P, Culine S, Iborra F, Mottet N, Soulie M . Les members du CCAFU : Recommendations en onco- urologie 2013 du CCAFU: tumeurs malignes du penis, Prog Urol. 2013; 23 (Suppl 2): S135-144. https://doi.org/10.1016/S11667087(13)70051-4

13. Koifman L, Hampl D, Koifman N et al. Radical open inguinal lymphadenectomy for penile carcinoma : surgical technique, early complications and late outcomes .JUrol. 2013 Dec; 190(6) : 2086-92. https://doi.org/10.1016/j.juro.2013.06.016

14. Lughezzani G, Catanzaro $\mathrm{M}$, Torelli $\mathrm{T}$ et al. The relationship between lymph node ratio and cancer-specific survival in a contemporary series of patients with penile cancer and lymph node metastases. BJU Int. 2013 Oct 15.

15. Catalona WJ. Modified inguinal lymphadenectomy for carcinoma of the penis with preservation of saphenous veins : Technique and preliminary results . J Urol . 1988 Aug; 140(2) : 306-10. https://doi.org/10.1016/S0022-5347(17)41589-8

16.Hakenberg OW, Protzel C. Chemotherapy in penile cancer. Ther Adv Urol 2012; 4: 133-8. https://doi.org/10.1177/1756287212441235

17. Heyns CF, Mendoza Valdes A, Pompeo AC. Diagnosis and staging of penile cancer. Urology 2010; 76 (2 Suppl 1): S15-23. https://doi.org/10.1016/j.urology.2010.03.002

18. McDougal WS. Carcinoma of the penis : improved survival by early regional lymphadenectomy based on the histological grade and depth of invasion of the primary lesion . J Urol 1995; 154: 1364-6. https://doi.org/10.1016/S0022-5347(01)66863-0

19. Lam W, Alnajjar HM, La-Touche S, et al. Dynamic sentinel lymph node biopsy in patients with invasive squamous cell carcinoma of the penis : a prospective study of the long-term outcome of 500 inguinal basins assessed at a single institution. Eur Urol 2013; 63 :657-63. https://doi.org/10.1016/j.eururo.2012.10.035

20. Leijte JAP, Kirrander P, Antonini N et al. Recurrence patterns of squamous cell carcinoma of the penis : recommendations for follow-up based on a two-centre analysis of 700 patients. Eur Urol . $2008 \mathrm{Jul} ;$ 54(1) : 161-8.

https://doi.org/10.1016/j.eururo.2008.04.016 